\title{
Lysine levels in diets for broilers from 8 to 21 days of age
}

\author{
Will Pereira de Oliveira1, Rita Flávia Miranda de Oliveira' ${ }^{1}$, Juarez Lopes Donzele ${ }^{1}$, \\ Luiz Fernando Teixeira Albino1, Paulo Henrique Reis Furtado Campos', Eric Márcio Balbino, \\ Ana Paula de Assis Maia ${ }^{1}$, Silvana Marques Pastore ${ }^{1}$
}

${ }^{1}$ Universidade Federal de Viçosa, Viçosa, MG, Brasil.

\begin{abstract}
This study was conducted to evaluate the effects of digestible lysine levels in diets with and without supplementation of industrial amino acids on performance and fat deposition in the carcass of broilers in the starter phase. One thousand four hundred and forty chickens with initial weight of $168.1 \pm 5.0 \mathrm{~g}$ were distributed in a completely randomized experimental design, in a $5 \times 2$ factorial arrangement, composed of five digestible lysine levels $(10.0,11.0,12.0,13.0$ and $14.0 \mathrm{~g} / \mathrm{kg}$ ) and two types of diet (diet with different proportions of corn and soybean meal and diet supplemented with industrial amino acids to obtain the digestible lysine levels), with eight replications and 18 birds per replication. There was interaction effect only on weight gain and fat deposition in the birds. The lysine levels reduced feed intake linearly in both diets, but caused a linear increase in lysine intake. The lysine levels quadratically affected weight gain and feed conversion, which improved up to the estimated levels of 13.0 and $12.8 \mathrm{~g} / \mathrm{kg}$ lysine, respectively, when the corn:soybean meal ratio of the diet changed. In the diets supplemented with amino acids, the lysine levels increased weight gain and improved feed conversion linearly. Regardless of the type of diet, protein deposition increased linearly, whereas fat deposition reduced also linearly, as the lysine levels in the diets were increased. The levels of 13.0 and $14.0 \mathrm{~g} / \mathrm{kg}$ digestible lysine provide, respectively, the best performance in birds fed a diet in which the proportion of corn and soybean meal varies and a diet supplemented with industrial amino acids, in the period from 8 to 21 days of age.
\end{abstract}

Key Words: crude protein, ideal protein, industrial amino acids, performance

\section{Introduction}

Broilers have genetic potential for rapid growth and elevated meat deposition in the carcass, and to ensure satisfactory production rates, research has been conducted aiming at the development of increasingly more appropriate diets to meet the nutritional requirements of these birds.

The dietary protein is considered the main nutrient to be converted and deposited as muscle tissue in the carcass (Suida, 2001). More precisely, it is understood that the nutritional requirement of a bird is composed mainly of amino acids, rather than only crude protein (Nascimento, 2004), which makes it indispensable to correctly determine the amino-acid requirements of birds to formulate diets that allow them to express their maximum genetic potential for production. Given that the exact balance of amino acids capable of meeting without excess or deficits the requirements of all essential amino acid has been expressed as percentage of lysine (Baker \& Han, 1994), inaccurate determination of the lysine requirement could result in imbalanced amino acids in the diet, reducing bird performance.
The method utilized to determine the lysine requirement employs the reduction of dietary crude protein and its supplementation with essential amino acids so that they are not below the bird requirements (Rostagno et al., 1999). Although it allows for reducing the amino-acid load of diets, enabling more accurate adjustments of their levels (Oliveira Neto \& Oliveira, 2009), the effects of this practice on bird performance have presented controversial results, demonstrating that the knowledge of the reduction of crude protein from diets supplemented with essential amino acid does not change performance or carcass characteristics of broilers; on the other hand, impaired performance and carcass quality and low yield in the cuts of broilers fed diets formulated by this method have been reported by several researchers (Aletor et al., 2000; Aftab et al., 2006; Assis et al., 2008; Namroud et al., 2008).

Thus, this study was conducted to determine the digestible lysine requirement for broilers from 8 to 21 days of age utilizing two diet-formulation methodologies: alteration of the proportion of corn and soybean meal, and supplementation of diets with industrial amino acids. 


\section{Material and Methods}

The experiment was carried out in the Poultry Sector of the Department of Animal Science of Universidade Federal de Viçosa, located in Viçosa/MG, Brazil.

One thousand four hundred and forty male Cobb broilers with initial weight of $168.1 \pm 5.0$. were used. The birds were vaccinated against Marek's and fowlpox diseases. During the starter phase (1 to 7 days of age), they were housed in groups of 18 birds in $2 \mathrm{~m}^{2}(2.0 \times 1.0 \mathrm{~m})$ pens in a conventional shed and received a diet formulated so as to meet their nutritional requirements, as recommended by Rostagno et al. (2005), and managed according to the manual of the strain (Cobb, 2005).

On the 8th day of age, the chicks were weighed and distributed into the pens in a completely randomized design, in a $5 \times 2$ factorial arrangement (five lysine levels and two methods of diet formulation), with eight replications and 18 birds per replication. All pens were provided with a bed, a tubular feeder and a nipple drinker.
The birds were fed the experimental diets (Tables 1 and 2), formulated on the basis of corn and soybean meal, and supplemented with minerals and vitamins to contain $10.0,11.0,12.0,13.0$ and $14.0 \mathrm{~g} / \mathrm{kg}$ digestible lysine, with 3,050 kcal ME. The lysine levels were obtained in two forms: by modifying the proportion of corn and soybean meal (CSM diet) and by supplementation with industrial amino acids (CSM + IAA diet), keeping the amounts of corn and soybean meal fixed. The other essential amino acids were supplemented as their ratios with digestible lysine were below those recommended in the ideal protein by Rostagno et al. (2005) (Table 3). The experimental diets and water were provided ad libitum.

The environmental conditions within the shed were recorded five times daily (at 7h30, 10h00, 12h30, 15h00 and 17h30) by a set of thermometers (dry bulb, wet bulb and black globe) kept at the center of the shed at the height of the body of the birds. The collected data were later converted into Globe Temperature and Humidity Index (WBGT) to characterize the environment, as proposed by Buffington et al. (1981).

Table 1 - Ingredients of the experimental diets whose lysine levels were obtained by modifying the proportion of corn and soybean meal

\begin{tabular}{|c|c|c|c|c|c|}
\hline \multirow{2}{*}{ Ingredient ( $\mathrm{g} / \mathrm{kg})$} & \multicolumn{5}{|c|}{ Digestible lysine level (g/kg) } \\
\hline & 10.0 & 11.0 & 12.0 & 13.0 & 14.0 \\
\hline Corn & 583.84 & 536.20 & 484.00 & 431.88 & 379.75 \\
\hline Soybean meal & 343.70 & 377.20 & 430.75 & 474.25 & 517.75 \\
\hline Vegetable oil & 30.65 & 39.18 & 47.72 & 56.23 & 64.76 \\
\hline Dicalcium phosphate & 18.38 & 18.19 & 18.00 & 17.80 & 17.60 \\
\hline Limestone & 9.08 & 8.97 & 8.86 & 8.76 & 8.65 \\
\hline Common salt & 5.02 & 5.03 & 5.03 & 5.03 & 5.03 \\
\hline Vitamin $\operatorname{mix}^{1}$ & 1.00 & 1.00 & 1.00 & 1.00 & 1.00 \\
\hline Mineral mixture $^{2}$ & 0.50 & 0.50 & 0.50 & 0.50 & 0.50 \\
\hline Anticoccidial $^{3}$ & 0.50 & 0.50 & 0.50 & 0.50 & 0.50 \\
\hline Antioxidant ${ }^{4}$ & 0.10 & 0.10 & 0.10 & 0.10 & 0.10 \\
\hline Choline chloride ${ }^{5}$ & 1.25 & 1.25 & 1.25 & 1.25 & 1.25 \\
\hline Avilamycin ${ }^{6}$ & 0.10 & 0.10 & 0.10 & 0.10 & 0.10 \\
\hline DL-methionine & 1.38 & 1.78 & 2.19 & 2.60 & 3.00 \\
\hline Total & $1,000.00$ & $1,000.00$ & $1,000.00$ & $1,000.00$ & $1,000.00$ \\
\hline \multicolumn{6}{|l|}{ Calculated composition } \\
\hline Crude protein $(\mathrm{g} / \mathrm{kg})$ & 205.2 & 220.8 & 236.5 & 252.1 & 267.8 \\
\hline Metabolizable energy (kcal/kg) & 3050 & 3050 & 3050 & 3050 & 3050 \\
\hline Digestible lysine $(\mathrm{g} / \mathrm{kg})$ & 10.0 & 11.0 & 12.0 & 13.0 & 14.0 \\
\hline Digestible methionine + cystine $(\mathrm{g} / \mathrm{kg})$ & 7.11 & 7.81 & 8.53 & 9.24 & 9.94 \\
\hline Digestible threonine $(\mathrm{g} / \mathrm{kg})$ & 6.98 & 7.53 & 8.07 & 8.61 & 9.15 \\
\hline Digestible tryptophan (g/kg) & 2.28 & 2.49 & 2.70 & 2.91 & 3.13 \\
\hline Digestible valine $(\mathrm{g} / \mathrm{kg})$ & 8.69 & 9.35 & 10.01 & 10.66 & 11.32 \\
\hline Digestible isoleucine (g/kg) & 8.13 & 8.83 & 9.53 & 10.23 & 10.93 \\
\hline Digestible arginine $(\mathrm{g} / \mathrm{kg})$ & 13.12 & 14.32 & 15.53 & 16.73 & 17.94 \\
\hline Digestible phenylalanine + tyrosine $(\mathrm{g} / \mathrm{kg})$ & 16.01 & 17.24 & 18.47 & 19.70 & 20.93 \\
\hline Sodium $(\mathrm{g} / \mathrm{kg})$ & 2.18 & 2.18 & 2.18 & 2.18 & 2.18 \\
\hline Calcium $(\mathrm{g} / \mathrm{kg})$ & 8.99 & 8.99 & 8.99 & 8.99 & 8.99 \\
\hline Available phosphorus (g/kg) & 4.49 & 4.49 & 4.49 & 4.49 & 4.49 \\
\hline
\end{tabular}

${ }^{1}$ Content/kg: vit. A - 15,000,000 IU; vit. D3 - 1,500,000 IU; vit. E - 15,000 IU; vit. B1 - 2.0 g; vit. B2 - 4.0 g; vit. B6 - 3.0 g; vit. B12 - 0.015 g; nicotinic acid - 25 g; patothenic acid - $10 \mathrm{~g}$; vit. K3 - $3.0 \mathrm{~g}$; folic acid - $1.0 \mathrm{~g}$; zinc bacitracin - $10 \mathrm{~g}$; selenium - $250 \mathrm{mg}$; antioxidant BHT - $10 \mathrm{~g}$; excipient q.s. - $1,000 \mathrm{~g}$.

${ }^{2}$ Content/kg: manganese - $80 \mathrm{~g}$; iron - $80 \mathrm{~g}$; zinc - $50 \mathrm{~g}$; copper - $10 \mathrm{~g}$; cobalt - $2 \mathrm{~g}$; iodine - $1 \mathrm{~g}$; excipient q.s. - $1,000 \mathrm{~g}$.

${ }^{3}$ Salinomycin sodium - $60 \mathrm{ppm}$.

${ }^{4}$ Butylated Hydroxytoluene.

${ }^{5}$ Choline chloride - $43.5 \mathrm{mg}$ choline.

${ }^{6}$ Avilamycin $10 \%$. 
Table 2 - Ingredients of the experimental diets whose lysine levels were obtained by supplementation with industrial amino acids

\begin{tabular}{|c|c|c|c|c|c|}
\hline \multirow{2}{*}{ Ingredient $(\mathrm{g} / \mathrm{kg})$} & \multicolumn{5}{|c|}{ Digestible lysine level (g/kg) } \\
\hline & 10.0 & 11.0 & 12.0 & 13.0 & 14.0 \\
\hline Corn & 552.00 & 552.00 & 552.00 & 552.00 & 552.00 \\
\hline Soybean meal & 346.70 & 346.70 & 346.70 & 346.70 & 346.70 \\
\hline Dicalcium phosphate & 18.51 & 18.51 & 18.51 & 18.51 & 18.51 \\
\hline Limestone & 09.01 & 09.01 & 09.01 & 09.01 & 09.01 \\
\hline Common salt & 5.04 & 5.04 & 5.04 & 5.04 & 5.04 \\
\hline Anticoccidial $^{3}$ & 0.50 & 0.50 & 0.50 & 0.50 & 0.50 \\
\hline Antioxidant ${ }^{4}$ & 0.10 & 0.10 & 0.10 & 0.10 & 0.10 \\
\hline Choline chloride ${ }^{5}$ & 1.25 & 1.25 & 1.25 & 1.25 & 1.25 \\
\hline Avylamicine ${ }^{6}$ & 0.10 & 0.10 & 0.10 & 0.10 & 0.10 \\
\hline DL-methionine & 1.46 & 2.19 & 0.291 & 0.364 & 0.436 \\
\hline Kaolin & 20.00 & 17.73 & 13.81 & 7.75 & 0.70 \\
\hline L-arginine & --- & --- & --- & 0.61 & 1.73 \\
\hline L-phenylalanine & --- & --- & --- & --- & 2.2 \\
\hline Total & $1,000.00$ & $1,000.00$ & $1,000.00$ & $1,000.00$ & $1,000.00$ \\
\hline \multicolumn{6}{|l|}{ Calculated composition } \\
\hline Crude protein $(\mathrm{g} / \mathrm{kg})$ & 203.6 & 205.4 & 208.8 & 214.9 & 222.2 \\
\hline Metabolizable energy $(\mathrm{kcal} / \mathrm{kg})$ & 3050 & 3060 & 3071 & 3084 & 3099 \\
\hline Digestible lysine $(\mathrm{g} / \mathrm{kg})$ & 10.00 & 11.00 & 12.00 & 13.00 & 14.00 \\
\hline Digestible methionine + cystine $(\mathrm{g} / \mathrm{kg})$ & 7.10 & 7.82 & 8.52 & 9.24 & 9.94 \\
\hline Digestible threonine $(\mathrm{g} / \mathrm{kg})$ & 6.93 & 7.15 & 7.80 & 8.46 & 9.11 \\
\hline Digestible tryptophan $(\mathrm{g} / \mathrm{kg})$ & 2.27 & 2.27 & 2.27 & 2.27 & 2.27 \\
\hline Digestible valine $(\mathrm{g} / \mathrm{kg})$ & 8.62 & 8.82 & 9.01 & 9.75 & 10.51 \\
\hline Digestible isoleucine $(\mathrm{g} / \mathrm{kg})$ & 8.09 & 8.09 & 8.09 & 8.46 & 9.11 \\
\hline
\end{tabular}

Table 3 - Composition in total and digestible amino acids, and dry matter and crude protein of the ingredients of the experimental diets

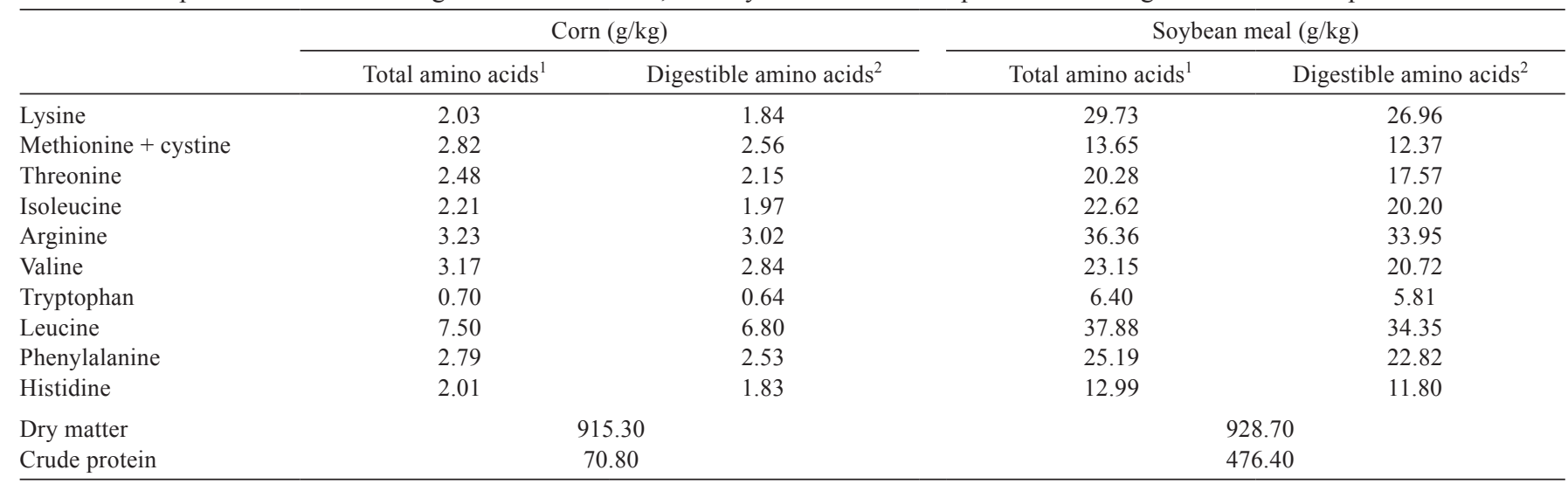

\footnotetext{
${ }^{1}$ Determined by the laboratory of AJINOMOTO - Biolatina.
}

${ }^{2}$ Calculated on the basis of the digestibility coefficients recommended by Rostagno et al. (2005). 
The lighting program adopted during the experimental period was continuous, with 24 hours of artificial light, utilizing 100-W incandescent light bulbs distributed above the pens across the experimental shed.

The birds were weighed at the beginning and end of the experimental period to determine weight gain. Feed intake was calculated as the difference between the total feed supplied and the remnants in the troughs. Feed conversion was calculated based on the feed intake and weight gain.

Completing 21 days of age, two birds of each experimental period with weight closest to the average of the replicate were slaughtered. Whole carcasses, including head and feet (without the feathers), viscera and blood were ground twice consecutively in an industrial meat grinder with production capacity of $700 \mathrm{~kg} / \mathrm{h}$, utilizing a disk with $5 \mathrm{~mm}$ perforations to obtain samples for determination of protein and fat deposition in the carcass.

An additional group of 80 birds at 8 days of age was slaughtered to determine the body composition at the beginning of the experiment. The carcass samples were initially pre-dried in a forced-ventilation oven at $60{ }^{\circ} \mathrm{C}$ for 72 hours. Subsequently, due to the high fat content, the carcasses were degreased in a Soxhlet extractor for 4 hours. After this stage, the samples were ground and subjected to laboratory analyses.

The analyses for determination of the ether extract and crude protein contents of the samples were performed according to the methods described by Silva \& Queiroz (2002).

The depositions of protein and fat in the carcass were calculated as the difference between the compositions of the carcasses of the broilers at 21 and 8 days of age. Chemical analyses of the diets were performed according to Silva \& Queiroz (2002).

The statistical analyses of the feed intake, weight gain, feed conversion and protein and fat deposition data were performed by utilizing computer software SAEG (Sistema para Análises Estatísticas, version 7.0), developed at Universidade Federal de Viçosa - UFV. The performance and carcass characteristics were subjected to variance analyses at $5 \%$ of probability. Polynomial regressions and/or Linear Response Plateau (LRP), analyses were applied according to the best fit of the data for each variable.

\section{Results and Discussion}

During the experiment, the average air temperatures and relative humidity measured within the shed (Table4) remained within the temperature range considered comfortable for the birds according to the manual of the strain (Cobb 500) for the 8-21 day phase. The thermoneutrality condition was confirmed by the calculation of the Globe Temperature and Humidity Index (WBGT) and is in accordance with Medeiros et al. (2005), who observed greater thermal comfort for broilers when the WBGT of the environment remained between 69 and 77.

For the results of feed intake, lysine intake, weight gain and feed conversion, lysine levels and diet-formulation methods interacted only on weight gain; however, there was also a significant interaction for fat deposition (Table 5).

The broilers that had been fed the diets whose lysine levels were obtained by adjusting the proportions of corn and soybean meal (CSM diet) showed a linear variation $(\mathrm{P}<0.01)$ in feed intake, which reduced according to the equation $\hat{\mathrm{Y}}=1,243.78-13.0556 \mathrm{X}$, having $\mathrm{r}^{2}=0.92$ (Table 6). This result differs from those found by Sterling et al. (2005), who observed increase in the feed intake of broilers fed diets with increasing lysine levels $(6.0,7.0,8.0$ and $9.0 \mathrm{~g} / \mathrm{kg}$ lysine in diets with 170.0, 200.0, 230.0 and $260.0 \mathrm{~g} / \mathrm{kg} \mathrm{CP}$, respectively) from 7 to 17 days, without the use of industrial lysine.

The differences in feed intake found in the literature for birds fed diets containing different lysine levels, obtained by variation in the protein levels or with industrial amino acids, seem to be related, among other factors, to the intensity of reduction in the $\mathrm{CP}$ levels and to the amino-acid profile of the diets (Aletor et al., 2000; Gonzales, 2002). According to Albino et al. (1999), deficiency or imbalance of amino acids may cause alteration in voluntary feed intake by birds. In this context, Swennen et al. (2004) reported that when the amino acids of a diet are at suboptimal levels, birds increase feed intake as an attempt to meet their requirements. Thus, it can be inferred that the higher intakes observed at the lowest levels of lysine in this study were proportional to its deficiency in the diet.

Although feed intake decreased, lysine intake increased $(\mathrm{P}<0.01)$ linearly as the concentration of this amino acid in the diet was elevated, according to the equations: $\hat{\mathrm{Y}}=1.90392+0.926281 \mathrm{X}\left(\mathrm{r}^{2}=0.99\right)$ and $\hat{\mathrm{Y}}=1.92453+$ $0.93226 \mathrm{X}\left(\mathrm{r}^{2}=0.99\right)$, respectively, for diets CSM and CSM + IAA. This response pattern demonstrated that the increase in the lysine levels among the treatments more than offset the decrease in feed intake.

The weight gain of birds fed diet CSM was quadratically influenced $(\mathrm{P}<0.02)$ by the lysine levels, increasing up to the estimated level of $13.0 \mathrm{~g} / \mathrm{kg}$. Likewise, the lysine levels of diet CSM + IAA also had a similar effect $(\mathrm{P}<0.01)$ on weight gain, which increased linearly (Figure 1). Similarly, in a study conducted with broilers until 18 days of age, Abdel-Maksoud et al. (2010) verified that regardless of the type of diet utilized (CSM or CSM + IAA), the lysine levels 
Table 4 - Climatic variables in the shed during the experimental period

\begin{tabular}{lccccc}
\hline \multirow{2}{*}{ Variable } & \multicolumn{4}{c}{ Time of reading } \\
\cline { 2 - 6 } & $07 \mathrm{~h} 00$ & $10 \mathrm{~h} 00$ & $12 \mathrm{~h} 30$ & $15 \mathrm{~h} 00$ & $17 \mathrm{~h} 30$ \\
\hline Air temperature $\left({ }^{\circ} \mathrm{C}\right)$ & $23.3 \pm 0.93$ & $25.9 \pm 0.73$ & $28.4 \pm 0.94$ & $28.7 \pm 0.99$ & $26.0 \pm 0.85$ \\
Relative air humidity (\%) & $81.2 \pm 2.90$ & $75.5 \pm 3.38$ & $65.7 \pm 3.41$ & $63.0 \pm 5.62$ & $73.3 \pm 3.95$ \\
Globe Temperature and Humidity Index & $71.9 \pm 1.35$ & $75.2 \pm 0.87$ & $77.7 \pm 1.07$ & $77.1 \pm 1.07$ & $75.0 \pm 0.94$ \\
\hline
\end{tabular}

Table 5 - Effect of lysine levels and diet-formulation methods on the performance and carcass characteristics of broilers from 8 to 21 days of age

\begin{tabular}{|c|c|c|c|c|c|c|}
\hline \multirow{2}{*}{ Factor } & \multicolumn{6}{|c|}{ Parameter evaluated } \\
\hline & Feed intake $(\mathrm{g})$ & Lysine intake (g) & Weight gain $(\mathrm{g})$ & Feed conversion $(\mathrm{g} / \mathrm{g})$ & Protein deposition $(\mathrm{g} / \mathrm{kg})$ & Fat deposition $(\mathrm{g} / \mathrm{kg})$ \\
\hline \multicolumn{7}{|l|}{ Lysine level (g/kg) } \\
\hline 10.0 & 1114.77 & 11.15 & 742.23 & 1.50 & 52.5 & 52.3 \\
\hline 11.0 & 1102.76 & 12.13 & 767.05 & 1.44 & 54.6 & 51.3 \\
\hline 12.0 & 1097.51 & 13.17 & 789.98 & 1.39 & 57.5 & 50.7 \\
\hline 13.0 & 1080.00 & 14.04 & 808.23 & 1.34 & 62.0 & 46.7 \\
\hline 14.0 & 1059.94 & 14.84 & 811.88 & 1.31 & 61.8 & 41.7 \\
\hline \multicolumn{7}{|l|}{ Diet-formulation method } \\
\hline CSMa & 1087.12 & 13.02 & 788.29 & 1.38 & 57.0 & 45.6 \\
\hline \multirow[t]{2}{*}{$\mathrm{CSM}+\mathrm{IAAb}$} & 1094.88 & 13.11 & 779.46 & 1.41 & 58.3 & 52.2 \\
\hline & & & & Probability & & \\
\hline Lysine level & 0.00001 & 0.00001 & 0.00001 & 0.00001 & 0.03372 & 0.00001 \\
\hline Diet-formulation method & 0.24529 & 0.25586 & 0.12844 & 0.02119 & 0.39841 & 0.00001 \\
\hline Lys level $\times$ DFM & 0.36554 & 0.31793 & 0.03682 & 0.20759 & 0.33230 & 0.01921 \\
\hline CV $(\%)$ & 2.71 & 2.76 & 3.27 & 3.61 & 25.53 & 10.54 \\
\hline
\end{tabular}

a - Digestible lysine levels obtained by modifying the amounts of corn and soybean meal in the diet.

$\mathrm{b}$ - Digestible lysine levels obtained by including industrial amino acids in the diet.

CSM - corn + soybean meal; IAA - industrial amino acids; Lys - lysine; DFM - diet-formulation method.

Table 6 - Performance values of broilers in the phase of 8 to 21 days of age according to the digestible lysine levels of the diet

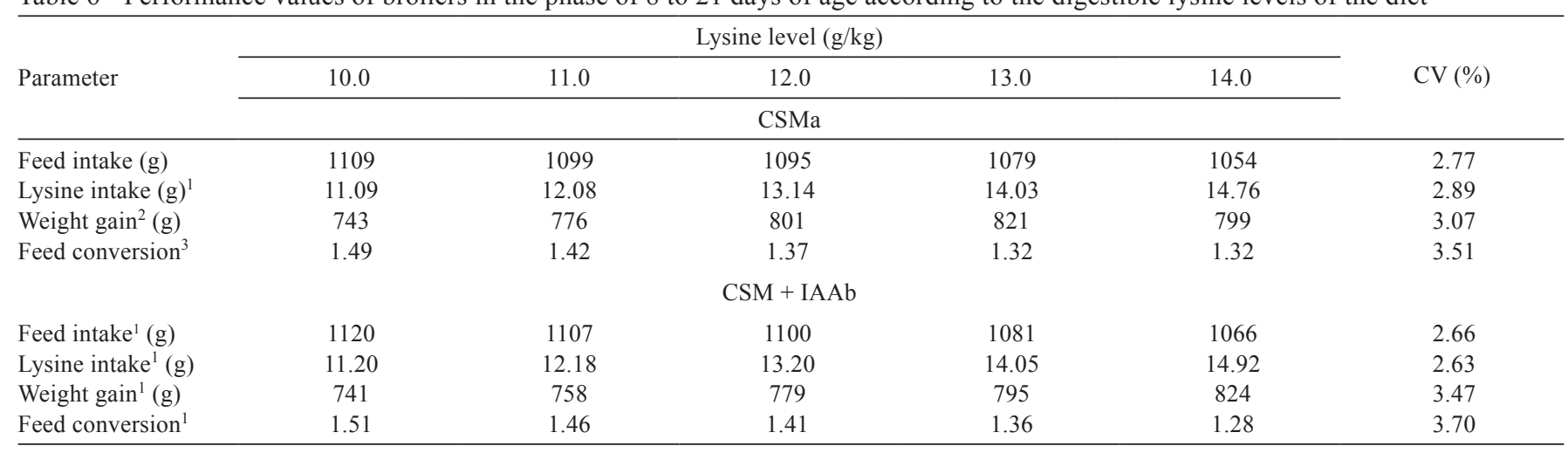

a - Digestible lysine levels obtained by modifying the amounts of corn and soybean meal in the diet.

$\mathrm{b}$ - Digestible lysine levels obtained by including industrial amino acids in the diet.

CSM - corn + soybean meal; IAA - industrial amino acids; CV - coefficient of variation.

${ }^{1}$ Linear effect $(\mathrm{P}<0.01)$

${ }^{2,3}$ Quadratic effect $(\mathrm{P}<0.02$ and $\mathrm{P}<0.01$, respectively).

affected weight gain in birds, whose best responses were obtained between 12.0 and $13.5 \mathrm{~g} / \mathrm{kg}$.

Positive effect of the dietary lysine levels on the growth rate of broilers was also observed by Conhalato et al. (1999), Costa et al. (2001, 2006), Rezaei et al. (2004), Lana et al. (2005), Amarante Júnior et al. (2005), Dozier et al. (2008), Goulart et al. (2008), Viola et al. (2009) and Abudabos \& Aljumaah (2010). Despite the consistency of the growth response to lysine, the level that provides the best results varies according to the studies, and this may be attributed to factors such as the ingredients utilized in the formulation of the diets; genetic potential of the birds for meat deposition in the carcass, among others (Leclercq \& Beaumont, 2001; Sterling et al., 2005; Indarsih, 2009).

The results demonstrated that the best response in weight gain of the broilers fed diets CSM + IAA occurred at a higher digestible lysine level than that which provided the best result when diet CSM was used $(14.0 \times 13.0 \mathrm{~g} / \mathrm{kg}$, 
respectively). This greater lysine requirement for weight gain when diet CSM + IAA was used would be an indicative that the relationship of an essential amino acid with lysine in the ideal protein would be underestimated. Assis et al. (2008) also found greater weight gain when the CSM diet was used in comparison with diet CSM + IAA, and this suggests that the requirement of this amino acid for broilers may vary according to the methodology adopted at the formulation of diets.

The reduction verified in weight gain at the level of $14.0 \mathrm{~g} / \mathrm{kg}$ lysine when diet CSM was used might be related to the elevated amino-acid concentration of the diet. According to Sklan \& Plavnik (2002), excess aminoacid intake results in energy expenditure by the bird in the deamination process and nitrogen excretion as uric acid. Still according to Goulart et al. (2008), the bird diverts the energy that would be used for tissue deposition to eliminate the excess nitrogen.

The feed conversion was influenced quadratically $(\mathrm{P}<0.01)$ by the increase in the lysine levels of the diets, obtained by adjustments in the proportion of corn and soybean meal (CSM), improving up to the estimated level of $14.0 \mathrm{~g} / \mathrm{kg}$ digestible lysine. Despite the quadratic variation, the Linear Response Plateau - LRP model was the best to fit the data, estimating the lysine level at $12.8 \mathrm{~g} / \mathrm{kg}$, from which there would be a plateau (Figure 2). When the diet CSM + IAA was used, however, feed conversion improved $(\mathrm{P}<0.01)$ linearly. In a study conducted with broilers from 22 to 42 days of age in a thermoneutral environment, Assis

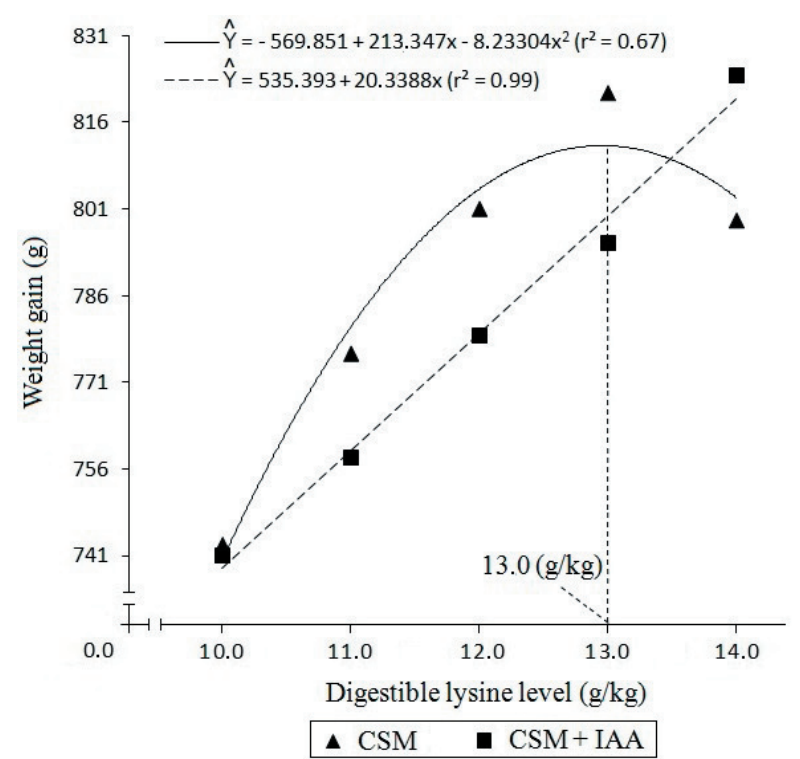

CSM - diet formulated with corn and soybean meal.

CSM + IAA - diet formulated with corn and soybean meal + industrial amino acids.

Figure 1 - Weight gain in broilers fed diets containing different lysine levels in the period of 8 to 21 days of age. et al. (2008) also observed effect of the lysine levels on diets formulated with corn and soybean meal only or supplemented with amino acids on the feed conversion of the animals.

Regardless of the type of diet utilized, several authors (Leclerq, 1998; Rezaei et al., 2004; Costa et al., 2006; Cella et al., 2009; Viola et al., 2009; Abdel-Maksoud et al., 2010; Ghahri et al., 2010) have also observed significant improvement of the feed conversion of broilers with increase in the lysine levels of their diets. The lysine levels that provided the best feed-conversion responses in this study $(14.0$ and $12.8 \mathrm{~g} / \mathrm{kg}$ ) were higher than the $11.0,11.9$ and $12.1 \mathrm{~g} / \mathrm{kg}$, respectively, recommended by the NRC (1994) and by Rostagno et al. $(2005 ; 2011)$. This result indicates that the levels recommended by the conventional tables do not meet the requirements of birds for maximum growth efficiency.

The fact that the best feed conversion obtained when $\operatorname{diet}$ CSM + IAA was used was achieved with a higher lysine level than that which provided the best response when diet CSM $(12.8 \times 14.0 \mathrm{~g} / \mathrm{kg} \mathrm{CSM} \mathrm{+} \mathrm{IAA)} \mathrm{was} \mathrm{used} \mathrm{confirms}$ the previous report, that the amino acid profile of the ideal protein proposed by Rostagno et al. (2011) for this animal category may not be adjusted to the bird requirements.

Considering the performance results, it can be inferred that the estimated lysine requirement for broilers in the starter phase of growth fed diets in which the lysine levels are obtained by supplementation of industrial amino acids is higher than that obtained by altering the corn and soybean meal proportions.

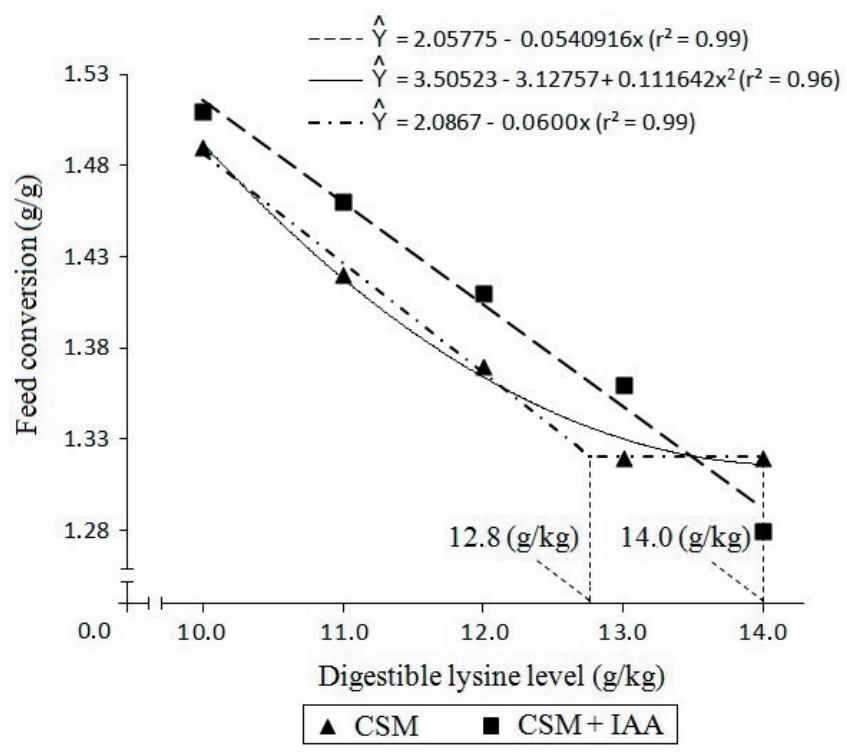

CSM - diet formulated with corn and soybean meal.

CSM + IAA - diet formulated with corn and soybean meal + industrial amino acids.

Figure 2 - Feed conversion of broilers fed diets containing different lysine levels in the period of 8 to 21 days of age. 
There was no interaction effect between the lysine levels and the diet-formulation method on the protein deposition of birds (Table 5). However, these factors had interaction effect on protein deposition (Table 7).

The protein deposition in the carcass increased linearly $(\mathrm{P}<0.06$ and $\mathrm{P}<0.02)$, respectively, as the lysine levels in the diet were increased, regardless of how (diets CSM and CSM + IAA) (Figure 3). This response pattern confirms the reports of Temim et al. (2000), Kidd et al. (2004), Corzo et al. (2004), Trindade Neto et al. (2009) and Ghahri et al. (2010), that the lysine requirement for maximum deposition of protein in the carcass is higher than that for maximum weight gain.

In experiments with chickens in the phases of 1 to 21 , 10 to 20 and 10 to 21 days of age, respectively, Conhalato et al. (1999), Edwards et al. (1999) and Eits et al. (2002) observed increased deposition of protein in the carcass as the lysine levels of the diet were elevated. However, these results differ from those found by Cella et al. (2009) and Tavernari et al. (2009), who did not observe variation in protein deposition in male broilers in the period of 1 to 21

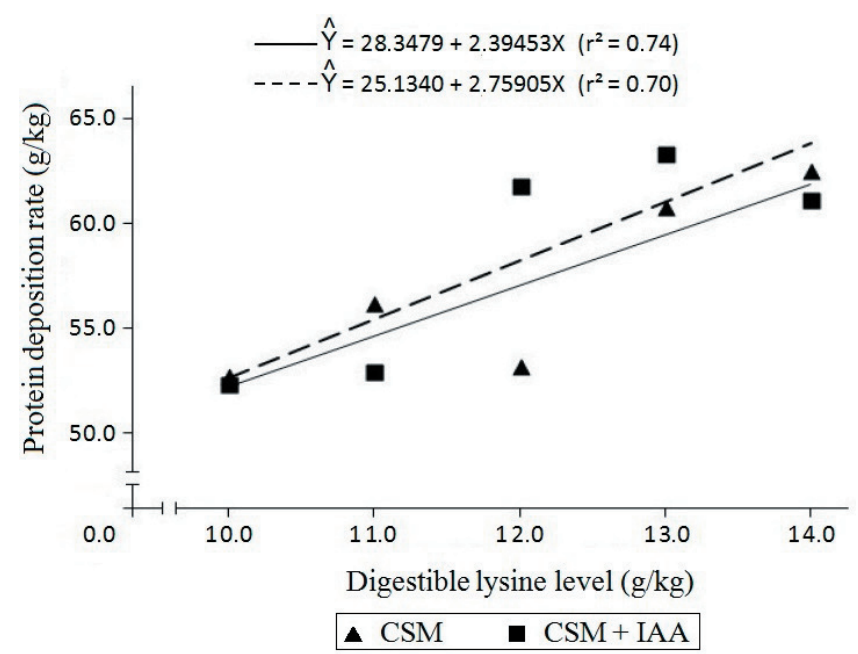

CSM - diet formulated with corn and soybean meal

CSM + IAA - diet formulated with corn and soybean meal + industrial amino acids.

Figure 3 - Protein deposition rate of broilers fed diets containing different lysine levels in the period of 8 to 21 days of age. days of age fed diets supplemented with 11.4, 11.8, 12.2 and $12.6 \mathrm{~g} / \mathrm{kg}$ and 10.73 and 11.60 and $12.47 \mathrm{~g} / \mathrm{kg}$ lysine, respectively. The variation in the results observed between the studies might be related to the lysine levels assessed, to the genetic potential of the birds for protein deposition in the carcass, and to the composition of the experimental diet.

The improvement in protein deposition with elevation in the concentration of lysine or CP in the two types of diet evaluated may be associated with the possible increase in the level of circulating IGF-1. Effect of protein levels on the serum concentration of IGF-1 in broilers has been reported by Caperna et al. (1999), Kita et al. (2002) and Nagao et al. (2010). In studies conducted with broilers from 1 to 7 days of age to evaluate the effect of protein levels in the diet, Kita \& Okumura (1999) associated the better muscle weight response of birds to the plasma IGF-1 levels.

For fat deposition (Table 8), there was interaction $(\mathrm{P}<0.02)$ between the lysine levels and the diet-formulation methods. Although both diets provided a linear decrease in this variable as the lysine levels were elevated (Figure 4), diet CSM promoted $(\mathrm{P}<0.01)$ greater intensity of reduction

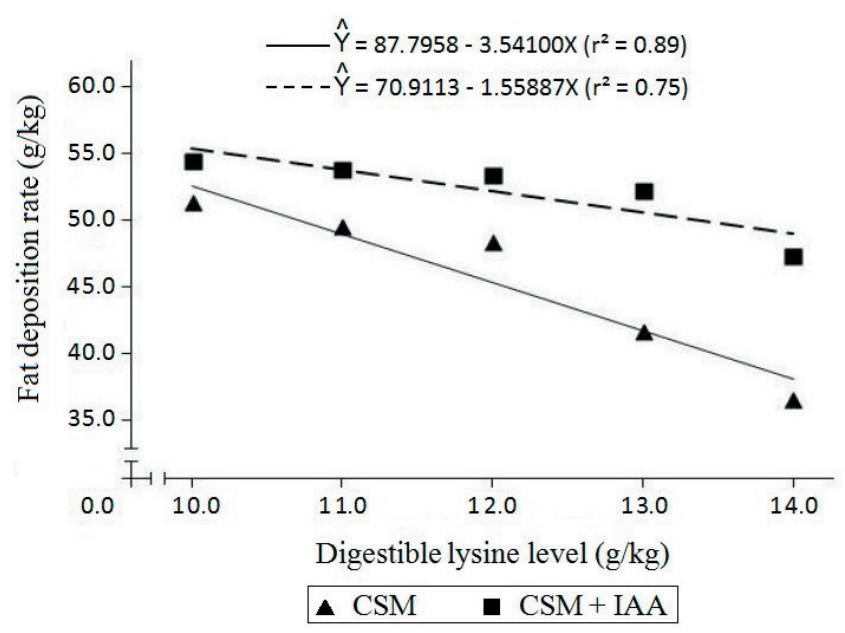

CSM - diet formulated with corn and soybean meal

CSM + IAA - diet formulated with corn and soybean meal + industrial amino acids.

Figure 4 - Fat deposition rate of broilers fed diets containing different lysine levels in the period of 8 to 21 days of age.

Table 7 - Protein deposition rate in the carcass of broilers in the phase of 8 to 21 days of age according to the digestible lysine levels in the diet

\begin{tabular}{|c|c|c|c|c|c|c|}
\hline \multirow{3}{*}{ Diet } & \multicolumn{5}{|c|}{ Lysine level (g/kg) } & \multirow{3}{*}{$\mathrm{CV}(\%)$} \\
\hline & 10.0 & 11.0 & 12.0 & 13.0 & 14.0 & \\
\hline & \multicolumn{5}{|c|}{ Protein (g/kg) } & \\
\hline CSMa & 52.7 & 56.2 & 53.2 & 60.8 & 62.5 & 26.78 \\
\hline $\mathrm{CSM}+\mathrm{IAAb}$ & 52.3 & 52.9 & 61.8 & 63.3 & 61.1 & 24.24 \\
\hline CV $(\%)$ & 0.26 & 0.31 & 0.25 & 0.24 & 0.21 & \\
\hline
\end{tabular}

a - Digestible lysine levels obtained by modifying the amounts of corn and soybean meal in the diet, with linear effect (P<0.06) for the lysine levels studied. b - Digestible lysine levels obtained by including industrial amino acids in the diet, with linear effect $(\mathrm{P}<0.02)$ for the lysine levels studied.

CSM - corn + soybean meal; IAA - industrial amino acids; CV - coefficient of variation. 
Table 8 - Fat deposition rate in the carcass of broilers in the phase of 8 to 21 days of age according to the digestible lysine levels in the diet

\begin{tabular}{|c|c|c|c|c|c|c|}
\hline \multirow{3}{*}{ Diet } & \multicolumn{5}{|c|}{ Lysine level (g/kg) } & \multirow{3}{*}{ CV (\%) } \\
\hline & 10.0 & 11.0 & 12.0 & 13.0 & 14.0 & \\
\hline & \multicolumn{5}{|c|}{ Protein $(\mathrm{g} / \mathrm{kg})$} & \\
\hline CSMa & 51.6 & 49.5 & 48.3 & 41.6 & 36.5 & 11.84 \\
\hline $\mathrm{CSM}+\mathrm{IAAb}$ & 54.4 & 53.8 & 53.3 & 52.2 & 47.2 & 9.17 \\
\hline $\mathrm{CV}(\%)$ & 0.10 & 0.11 & 0.11 & 0.17 & 0.18 & \\
\hline
\end{tabular}

a - Digestible lysine levels obtained by modifying the amounts of corn and soybean meal in the diet, with linear effect ( $<<0.01)$ for the lysine levels studied.

$\mathrm{b}$ - Digestible lysine levels obtained by including industrial amino acids in the diet, with linear effect $(\mathrm{P}<0.01)$ for the lysine levels studied.

$\mathrm{CSM}$ - corn + soybean meal; IAA - industrial amino acids; CV - coefficient of variation.

of fat deposition as compared with diet CSM + IAA. This result is different from those found by Tavernari et al. (2009) and Takeara et al. (2010), who did not find variations in the fat deposition of broilers from 1 to 21 and 12 to 22 days of age, respectively, fed diets containing, respectively, 10.73, 11.60 and $12.47 \mathrm{~g} / \mathrm{kg}$ and $10.5,11.0$, $11.5,12.0$ and $12.5 \mathrm{~g} / \mathrm{kg}$ lysine.

The divergence in the results found in the literature for deposition of protein and fat in the carcass may be related not only to the lysine content of the diet, but also to the genetic strain and to the age of the birds utilized as well as the thermal-environmental factors, immunologic challenge, among others (Costa et al., 2001; Borges et al., 2002; Enting et al., 2005; Lemme, 2005; Swennen et al., 2006).

The results have shown that both the increase in the lysine levels and the diet-formulation method changed the composition of gain in birds, providing greater protein and lower fat contents in the carcass.

The variations observed in the depositions of protein and fat in this study corroborate Leclercq (1998) and Gous (1998; 2007), who state that increase in the limiting aminoacid concentration in the diet potentiates the deposition of protein and reduces fat deposition in broilers. Thus, reduction in the amount of fat in the carcass when higher lysine levels are used can be attributed to the increased energy expenditure for protein deposition and maintenance of greater muscle mass, providing a lower amount of energy for fat deposition (Leeson, 1995). On the other hand, the $\mathrm{CP}$ content of the diets may influence the physiological mechanisms of growth of broilers, such as the plasma levels of IGF-1 (Kita \& Okumura, 1999) and thyroid hormones (Namroud et al., 2010), modifying the depositions of protein and fat in birds (Carew et al., 1998).

Therefore, it can be inferred that the diet-formulation method may interfere with the determination of the lysine requirement and that the practice of crude protein reduction is a hardly suitable method, because it generates other sources of variations that may affect the results.

\section{Conclusions}

The estimated digestible lysine levels of 13.0 and $12.8 \mathrm{~g} / \mathrm{kg}$ in diets whose levels of these amino acids are obtained by variation in the proportion of corn and soybean meal provide, respectively, better weight gain and feed conversion in birds. In birds fed diets supplemented with industrial amino acids, the level of $14.0 \mathrm{~g} / \mathrm{kg}$ lysine in the diet provides the best performance.

\section{References}

ABDEL-MAKSOUD, A.; YAN, F.; CERRATE, S. et al. Effect of dietary crude protein, lysine level and amino acid balance on performance of broilers 0 to 18 days of age. International Journal of Poultry Science, v.9, p.21-27, 2010.

ABUDABOS, A.; ALJUMAAH, R. Evaluation of digestible lysine needs for male broiler. International Journal of Poultry Science, v.9, p.1146-1151, 2010.

AFTAB, U.; ASHRAF, M.; JIANG, Z. Low protein diets for broilers. World's Poultry Science Journal, v.62, p.688-701, 2006.

ALBINO, L.F.T.A.; SILVA, S.H.M.; VARGAS, J.G. et al. Níveis de metionina + cistina para frangos de corte de 1 a 21 e 22 a 42 dias de idade. Revista Brasileira de Zootecnia, v.28, p.519-525, 1999.

ALETOR, V.A.; HAMID, I.I.; NIESS, E. et al. Low-protein amino acid-supplemented diets in broiler chickens: effects on performance, carcass, characteristics, whole-body, composition and efficiencies of nutrient utilization. Journal of the Science of Food and Agriculture, v.80, p.547-554, 2000.

AMARANTE JÚNIOR, V.S.; COSTA, F.G.P.; BARROS, L.R. et al. Níveis de lisina para frangos de corte nos períodos de 22 a 42 e de 43 a 49 dias de idade, mantendo a relação metionina + cistina. Revista Brasileira de Zootecnia, v.34, p.1188-1194, 2005.

ASSIS, A.P.; BALBINO, E.M.; CAMPOS, P.H.R.F. et al. Níveis de lisina em rações para frangos de corte machos mantidos em termoneutralidade dos 22 aos 42 dias de idade. In: Zootec 2008, 2008, João Pessoa. Anais... João Pessoa, 2008. (CD-ROM).

BAKER, D.H.; HAN, Y. Ideal amino acid profile for chickens during the first three weeks posthatching. Poultry Science, v.73, p.1441-1447, 1994.

BORGES, A.F.; OLIVEIRA, R.F.M.; DONZELE, J.L. et al. Exigência de lisina para frangos de corte machos no período de 22 a 42 dias de idade, mantidos em ambiente quente $\left(26^{\circ} \mathrm{C}\right)$. Revista Brasileira de Zootecnia, v.31, p.1993-2001, 2002.

BUFFINGTON, D.E.; COLLAZO-AROCHO, A.; CANTON, G.H. et al. Black globe humidity index (BGHI) as a comfort equation for dairy cows. Transactions of the American Society of Agricultural Engineers, v.24, p.711-714, 1981. 
CAPERNA, T.J.; ROSEBROUGH, R.W.; MCMURTRY, J.P. et al. Influence of dietary protein on insulin-like growth factor binding proteins in the chicken. Comparative biochemistry and physiology - Parte B: Biochemistry Molecular Biology, v.124, p.417-421, 1999.

CAREW, L.B.; EVARTS, K.G.; ALSTER, F.A. Growth, feed intake, and plasma thyroid hormone levels in chicks fed dietary excesses of essential amino acids. Poultry Science, v.77, p.295-298, 1998.

CELLA, P.S.; MURAKAMI, A.E.; FRANCO, J.R.G. Níveis de lisina digestível em dietas baseadas no conceito de proteína ideal para frangos de corte na fase inicial. Ciência Animal Brasileira, v.10, p.101-106, 2009.

COBB. Guia de manejo para frangos de corte cobb 500. S.I.: s.n., 2005. 58p.

CONHALATO, G.S.; DONZELE, J.L.; ROSTAGNO, H.S. et al. Níveis de lisina digestível para pintos de corte machos na fase de 1 a 21 dias de idade. Revista Brasileira de Zootecnia, v.28, p.91-97, 1999.

CORZO, A.; MORAN, E.T.; HOEHLER, D. Valine needs of male broilers from 42 to 56 days of age. Poultry Science, v.83, p.946-951, 2004.

COSTA, F.G.P.; AMARANTE JÚNIOR, V.S.; NASCIMENTO, G.A.J. et al. Níveis de lisina para frangos de corte nos períodos de 22 a 42 e de 43 a 49 dias de idade. Revista Brasileira de Zootecnia, v.30, p.759-766, 2006.

COSTA, F.G.P.; ROSTAGNO, H.S.; ALBINO, L.F.T. et al. Níveis dietéticos de lisina para frangos de corte de 1 a 21 e 22 a 40 dias de idade. Revista Brasileira de Zootecnia, v.30, p.1490-497, 2001.

DOZIER, W.A.; CORZO, A.; KIDD, M.T. et al. Dietary digestible lysine requirements of male and female broilers from forty-nine to sixty-three days of age. Poultry Science, v.87, p.1385-1391, 2008.

EDWARDS, H.; FERNANDEZ, S.R.; BAKER, D.H. Maintenance lysine requirement and efficiency of using lysine for accretion of whole-body lysine and protein in young chicks. Poultry Science, v.78, p.1412-1417, 1999.

EITS, R.M.; KWAKKEL, R.P.; VERSTEGEN, M.W.A. Nutrition affects fat-free body composition in broiler chickens. The Journal of Nutrition, v.132, p.2222-2228, 2002.

ENTING, H.; VELDMAN, B.; POS, J. et al. Factors that influence nutritional requirements of poultry. In: SIMPÓSIO INTERNACIONAL SOBRE EXIGÊNCIAS NUTRICIONAIS DE AVES E SUÍNOS, 2005, Viçosa, MG. Anais... Viçosa, MG, 2005. p.97-116.

GHAHRI, H.; GAYKANI, R.; TOLOIE, T. Effect of dietary crude protein level on performance and Lysine requirements of male broiler chickens. African Journal of Agricultural Research, v.5, p.1228-1234, 2010.

GONZALES, E. Ingestão de alimentos: mecanismos regulatórios. In: MACARI, M.; FURLAN, R.L.; GONZALES, E. (Eds.). Fisiologia aviária aplicada a frangos de corte. 2.ed. Jaboticabal: FUNEP, 2002. p.187-199.

GOULART, C.C.; COSTA, F.G.P.; LIMA NETO, R.C. et al. Exigência de lisina digestível para frangos de corte machos de 1 a 42 dias de idade. Revista Brasileira de Zootecnia, v.37, p.876-882, 2008.

GOUS, R.M. Making progress in the nutrition of broilers. Poultry Science, v.77, p.111-117, 1998 .

GOUS, R.M. Methodologies for modeling energy and amino acid responses in poultry. Revista Brasileira de Zootecnia, v.36, p.263-275, 2007 (Supl. especial).

INDARSIH, B. Response of two different strains of commercial broilers to different dietary amino acid allowance. Media Peternakan, v.32, p.104-111, 2009.

KIDD, M.T.; MCDANIEL, C.D.; BRANTON, S.L. et al. Increasing amino acid density improves live performance and carcass yields of commercial broilers. Journal Applied Poultry Research, v.13, p.593-604, 2004

KITA, K.; NAGAO, K.; TANEDA, N. et al. Insulin-like growth factor binding protein-2 gene expression can be regulated by diet manipulation in several tissues of young chickens. Journal of Nutrition, v.132, p.145-151, 2002.

KITA, K.; OKUMURA, J. Dietary protein levels alter plasma insulinlike growth factor-I concentration of chicks. Japanese Poultry Science, v.36, p.25-30, 1999.

LANA, S.R.V.; OLIVEIRA, R.F.M.; DONZELE, J.L. et al. Níveis de lisina digestível em rações para frangos de corte de 22 a 42 dias de idade, mantidos em ambiente de termoneutralidade. Revista Brasileira de Zootecnia, v.34, p.1624-1632, 2005.

LECLERCQ, B.; BEAUMONT, C. Effects of genetic potential on the lysine requirement and economic results of simulated broiler flocks. Animal Research, v.50, p.67-78, 2001.

LECLERQ, B. Specific effects of lysine on broiler production: comparison with threonine and valine. Poultry Science, v.77, p.118-123, 1998.

LEESON, S. Nutrição e qualidade de carcaca de frangos de corte. In: CONFERÊNCIA APINCO DE CIÊNCIA E TECNOLOGIA AVÍCOLAS, 1995, Curitiba. Anais... Curitiba: Fundação Apinco de Ciência e Tecnologias Avícolas, 1995. p.111-118.

LEMME, A. Optimum dietary amino acid level for broiler chicken. In: SIMPÓSIO INTERNACIONAL SOBRE EXIGÊNCIAS NUTRICIONAIS DE AVES E SUÍNOS, 2., 2005, Viçosa, MG. Anais... Viçosa, MG: Universidade Federal de Viçosa, 2005. p.117-144.

MEDEIROS, C.M.; BAETA, F.C.; OLIVEIRA, R.F.M.et al. Efeitos da temperatura, umidade relativa e velocidade do ar em frangos de corte. Engenharia na Agricultura, v.13, p.277-286, 2005.

NAGAO, K.; HIRAMATSU, K.; TSUKADA, A. et al. Effects of insufficient level of dietary protein on IGF-I and IGFBPs in young chickens. Journal of Poultry Science, v.47, p.236-239, 2010.

NAMROUD, N.F.; SHIVAZAD, M.; ZAGHARI, M. Effects of fortifying low crude protein diet with crystalline amino acids on performance, blood ammonia level, and excreta characteristics of broiler chicks. Poultry Science, v.87, p.2250-2258, 2008.

NAMROUD, N.F.; SHIVAZAD, M.; ZAGHARI, M. et al. Effects of glycine and glutamic acid supplementation to low protein diets on performance, thyroid function and fat deposition in chickens. South African Journal of Animal Science, v.40, p.238-244, 2010.

NASCIMENTO, A. Exigências de aminoácidos essenciais para frangos de corte. In: CONFERÊNCIA APINCO DE CIÊNCIA E TECNOLOGIA AVÍCOLAS, 2004, Santos. Anais... Santos: Fundação Apinco de Ciência e Tecnologias Avícolas, 2004. p.103-116.

NATIONAL RESEARCH COUNCIL - NRC. Nutrient requirements of poultry. Nutrient requirements of domestic animals. 9.ed. Washington: National Academic, 1994. 155p.

OLIVEIRA NETO, A.R.; OLIVEIRA, W.P. Aminoácidos para frangos de corte. Revista Brasileira de Zootecnia, v.38, p.205-208, 2009 (Supl. especial).

REZAEI, M.; MOGHADDAM, H.N.; REZA, J.P. et al. The effects of dietary protein and lysine levels on broiler performance, carcass characteristics and $\mathrm{n}$ excretion. International Journal of Poultry Science, v.3, p.148-152, 2004.

ROSTAGNO, H.S.; ALBINO, L.F.T.; DONZELE, J.L. et al. Tabelas brasileiras para aves e suínos: composição de alimentos e exigências nutricionais. 2.ed. Viçosa, MG: UFV, Departamento de Zootecnia, 2005. 186p.

ROSTAGNO, H.S.; ALBINO, L.F.T.; DONZELE, J.L. et al. Tabelas brasileiras para aves e suínos: composição de alimentos e exigências nutricionais. 3.ed. Viçosa, MG: UFV, Departamento de Zootecnia, 2011. 252p.

ROSTAGNO, H.S.; NASCIMENTO, A.H.; ALBINO, L.F.T. Aminoácidos totais e digestíveis para aves. In: CONFERÊNCIA APINCO DE CIÊNCIA E TECNOLOGIA AVÍCOLAS, 1999, Campinas. Anais... Campinas: Fundação Apinco de Ciência e Tecnologias Avícolas, 1999. p.65-83

SILVA, D.J.; QUEIROZ, A.C. Análise de alimentos: métodos químicos e biológicos. 3.ed. Viçosa, MG: UFV, 2002. 235p. 
SKLAN, D.; PLAVNIK, I. Interactions between dietary crude protein and essential amino acid intake on performance in broilers. British Poultry Science, v.43, p.442-449, 2002.

STERLING, K.G.; VEDENOV, D.V.; PESTI, G.M. et al. Economically optimal dietary crude protein and lysine levels for starting broiler chicks. Poultry Science, v.84, p.29-36, 2005.

SUIDA, D. Formulação por proteína ideal e conseqüências técnicas econômicas e ambientais. In: SIMPÓSIO INTERNACIONAL DE NUTRIÇÃO ANIMAL: Proteína ideal, energia líquida e modelagem, 2001, Santa Maria. Anais... Santa Maria: Empresa Brasileira de Pesquisa Agropecuária, 2001. p.27-43.

SWENNEN, Q.; JANSSENS, G.P.J.; COLLIN, A. et al. Diet-induced thermogenesis and glucose oxidation in broiler chickens: influence of genotype and diet composition. Poultry Science, v.85, p.731-742, 2006.

SWENNEN, Q.; JANSSENS, G.P.J.; DECUYPERE, E. et al. Effects of substitution between fat and protein on feed intake and its regulatory mechanisms in broiler chickens: Energy and protein metabolism and diet-Induced thermogenesis. Poultry Science, v.83, p.1997-2004, 2004.
TAKEARA, P.; TOLEDO, A.L.; GANDRA, E.R.S. et al. Lisina digestível para frangos de corte machos entre 12 e 22 dias de idade. Arquivo Brasileiro de Medicina Veterinária e Zootecnia, v.62, p.1455-1461, 2010.

TAVERNARI F.C.; BUTERI, C.B.; ROSTAGNO, H.S. et al. Effects of dietary digestible lysine levels on protein and fat deposition in the carcass of broilers. Revista Brasileira de Ciência Avícola, v.11, p.99-107, 2009.

TEMIM, S.; CHAGNEAU, A.M.; GUILLAUMMIN, S. et al. Does excess dietary protein improve growth performance and carcass characteristics in heat-exposed chickens. Poultry Science, v.78, p.312-317, 2000.

TRINDADE NETO, M.A.; TAKEARA, P.; TOLEDO, A.L. et al. Níveis de lisina digestível para frangos de corte machos no período de 37 a 49 dias de idade. Revista Brasileira de Zootecnia, v.38, p.508-514, 2009.

VIOLA, T.H; KESSLER, A.M.; RIBEIRO, A.M.L. et al. Desempenho e peso de frações corporais, na suplementação crescente de lisina, dos 19 aos 40 dias de idade em frangos de corte. Ciência Rural, v.39, p.515-521, 2009. 